parisons with the present day. Some is also very bad. An important summarizing paragraph opens with this almost impenetrable and quite unforgivable sentence: "The affinities of the Saliagos culture are not so marked in the case of any one culture as to single out the latter as a likely point of departure for the inhabitants of Saliagos".

In Excavations at Saliagos we have a large volume devoted to a small and uncomplicated site. It is a significant littlo site, undoubtedly, yet until recently a substantial paper in a periodical would have been considered sufficient to describe it. In view of what I wrote recently in this journal on the Haua Fteah report (Nature, 218, 1181; 1968) I feel it to be a duty to return to this subject of conspicuous waste in the publication of scientific archaeology. In comparison with the earlier volume, this one took only three years instead of ten, and costs only 5 gns instead of $£ 12$ (the costs were met by the Cambridge Faculty Board of Classics). These are already considerable figures for an excavation of this kind.

Many archaeological scientists will find these criticisms entirely wrong-headed; yet nobody can honestly deny that they relate to serious problems. One answer might be that the full rigour of analytical archaeology should be encouraged in those who have faith in it (with the proviso that they should do their work at top speed to avoid the danger, foreseen by Professor Grahame Clark, of dying before its completion) but that there should be far more selectivity in what is published. Even very full verbal summaries supported by essential figures and illustrations would be slim in comparison with these volumes. The working papers, of interest to very few, could then be held for inspection together with the finds themselves, or made available through photostats. Such ideas are worth discussion.

JACQUETTa Hawkes

\section{BIOLOGY FOR BANK CLERKS}

Mr Tompkins Inside Himself

Adventures in the New Biology. By George Gamow and Martynas Ycas. Pp. xiv +274 . (Allen and Unwin: London, 1968.) 35s.

A SPARRow is really a highly modified dinosaur, $\mathrm{Mr}$ Tompkins is told by Charles Darwin, one of the several distinguished cicerones coopted to conduct this innumerate bank clerk through the kingdom of the new biology. With an exuberance of wit and imagination Gamow and Yěas describe the intricacies of protein synthesis, molccular evolution, biogenesis and other growing points of current biological research. The non-scientist, for whom the book is intended, will appreciate the lucidity of their exposition and the pace of their narrative, whilst the scientist will recognize the enviable skill with which they describe complex things simply, yet at no expense of accuracy.

Mr Tompkins enters a Brobdingnagian world where mitochondria are graphically sliced open by kitchen knives, bacteria are as big as dogs and creatures looking like tadpoles attack and enter them. Thinly disguised celcbritics take turns by chapter to eonduct Mr Tompkins around their specialty; Herr Max the phage trainer explains about viruses, Saint about muscle contraction and a Dr Exkins about X-ray crystallography. In a dream $\mathrm{Mr}$ 'Tompkins communes with Charles Darwin, and it is good to learn from Darwin's own lips that "here in Dreamland we receive immediately the latest issues of all scientific publications such as Nature and Scientific American". It is less uplifting to hear that both "ignose" and "Godnose" were rejected as names for the sugar molecule of unknown structure discovered to be vitamin $\mathrm{C}$ because "at that time the editors of Nature were serious people, but unfortunately without a molecule of humour in their cerebral cortices". Darwin's discourse on evolution, informed of course by the very latest results, is one of the bost in the book, and $\mathrm{Mr}$

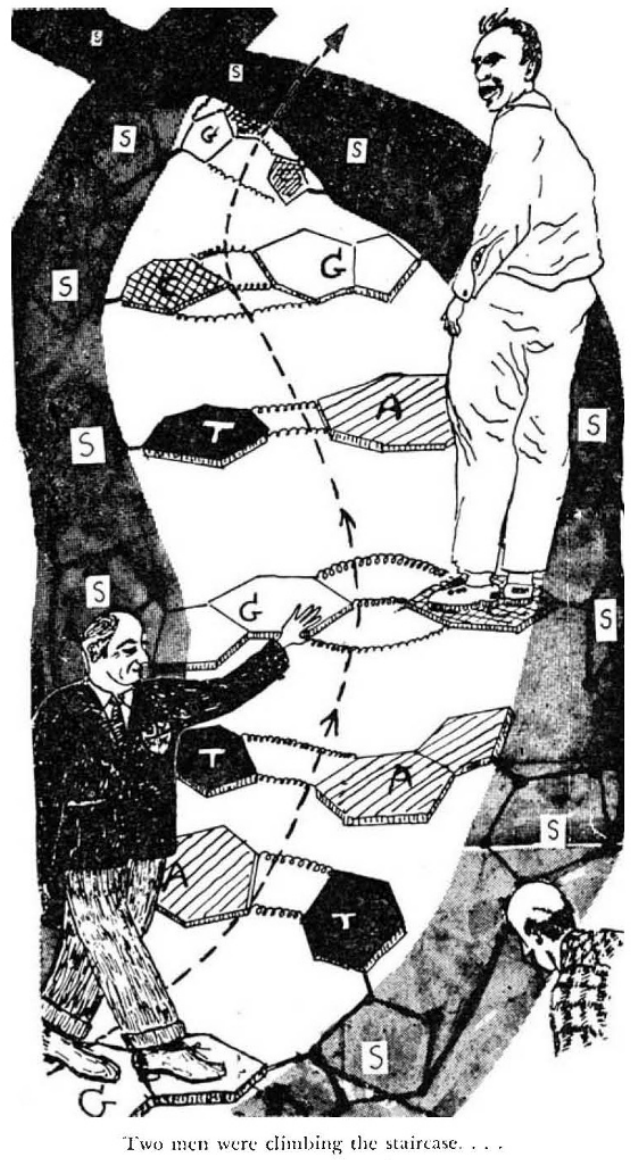

(From Mr Tompkins Inside Himself.)

Tompkins's journey, which begins with the solipsistic experience of being injected inside himself, ends with an enthralling disquisition on entropy, cosmology and the possibilities of extraterrestrial life. NrCHOLAs WAdE

\section{CULTURAL DIVIDE}

\section{Science and English Poetry}

A Historical Sketch, 1590-1950. By Douglas Bush. (The Patten Lectures, 1949, Indiana University.) Pp. vii + 166. (Oxford University Press : London and New York, 1967.) $10 s$.

WHEN the first edition of Science and English Poetry appeared in 1950 it earned a lavish review in Nature from Professor Andrade, and it scems churlish not to repeat the compliment for the second edition. But either charity has declined or expectations have risen in tho eighteen year interim, for it is hard to feel much enthusiasm for the book today.

Douglas Bush traces the effects of science on English poetry from the Renaissance to the present, and it goes without saying that he judges that the effects have been bad. His objections to science seem to be two-fold. First, arid explanation has replaced fertile myth. The Moon is no longer the cool mistress of the tides of love: now it is a lump of dusty rock violated by space probes. Second, by making the environment, and even the mind, of man subject to manipulation, it corrodes the basis of moral struggle.

Surely the first objection raises little steam nowadays. Aldous Huxley was able not so long ago to rebuke the poets for misinterpreting the ecological value of the nightingale's song, but, thankfully, few comments of this 